\title{
Review
}

\section{John Rawls: The path to a theory of justice}

\author{
Andrius Gališanka \\ Harvard University Press, Cambridge, 2019, 261 pp., \\ ISBN: 978-0674976474
}

Contemporary Political Theory (2021) 20, S71-S74. https://doi.org/10.1057/s41296020-00394-5; published online 6 April 2020

It has become a commonplace when discussing Rawls' biography to note that he lost his religious faith while fighting in World War II. In his new intellectual biography of John Rawls, Andrius Gališanka not only describes how Rawls' loss of a close friend in the war was a formative experience that prompted this loss (pp. 39-40), but also situates this event in the broader context of Rawls' life. We learn that Rawls came from a non-religious household and that his religiosity was sparked by the heated debate between the neo-orthodox and liberal Protestantism he encountered during his undergraduate studies at Princeton. One of Gališanka's many contributions in this book is to draw attention to the more enduring liberal Protestant qualities of Rawls' religious thought in his later political philosophy. In his senior thesis, for example, Rawls operated from the liberal Protestant premise that the task of the philosopher is to justify conceptual frameworks by how well they explain Christian experience. (This is in contrast to the neo-orthodox view that relies on revelation rather than experience.) Once he lost his faith, Rawls' philosophy no longer concerned itself with Christian experience, but Rawls nonetheless maintained the view that philosophy is an analysis of human experience (p. 40). This liberal Protestant emphasis on experience persisted as decades later Rawls exhorted his students not to conceive of ethics as merely the analysis of concepts and definitions (pp. 142-143) and as he adopted the method of reflective equilibrium in his later writings, according to which considered principles must be balanced against particular judgments as we experience them. Over the course of seven chapters, Gališanka enriches the anecdote of Rawls' time in World War II and draws out a thread of intellectual growth from this early event that stretches across several decades of his life. Readers of this terrific book are rewarded not only with a compelling narrative of the genesis of Rawls' ideas but also come to see, through Gališanka's careful reconstruction, the maturation, and ultimate invocation of these ideas in A Theory of Justice (hereafter Theory).

(c) 2020 Springer Nature Limited. 1470-8914 Contemporary Political Theory Vol. 20, S2, S71-S74 
Of particular merit is chapter six, which draws out the profound influence of Wittgenstein on Rawls' thinking. That Rawls would have engaged with Wittgenstein's philosophy is of little surprise, given that he went to Oxford on a Fulbright Fellowship from 1952 to 1953 and studied with Wittgenstein's student Norman Malcolm. However, a new reader of Theory would be excused for assuming Wittgenstein played little role in the book, since he receives only two citations in over 600 pages. It is therefore welcome and illuminating to follow Gališanka through the archives of Rawls' notes and unpublished works to appreciate just how extended Rawls' engagement with Wittgenstein was. These archives contain pages and pages dedicated to close study of Philosophical Investigations: summarizing the text, dividing it into themes, and even creating an index for the book. Under the influence of Wittgenstein's thought, Rawls came to view morality as a form of life where ethics is more than conceptual analysis; rather, it is a "natural phenomenon, as a complex of thought, feeling and action continuous with other aspects of human life' (pp. 115-116). We can trace to this period Rawls' optimism that he could produce moral agreement on principles of justice due to a shared moral nature, including a sense of justice. So, too, can we locate the philosophical rudiments of Rawls' crucial belief that his principles of justice as fairness would produce a stable polity as they would win the allegiance of citizens who shared natural moral sympathies, including reciprocity. The opening of Rawls' archives has prompted several other articles and books that discuss Wittgenstein's considerable intellectual influence on Rawls (Bok 2017; Forrester 2019, pp. 1-18). But in Gališanka's hands this insight comes with added significance because Wittgenstein's influence is placed in the context of Rawls' broader intellectual development, even if it is not directly cited by Rawls in Theory.

Rawls' increasing recognition of the 'fact of pluralism' and the persistence of disagreement among citizens receives quick but careful treatment. As the book carries the subtitle 'The Path to A Theory of Justice,' it would be wrong to criticize the book for its brisk recounting of these later developments in Rawls' thought. But even without the slow pace of analysis of events after the publication of Theory, Gališanka equips the reader to engage with these changes in an enlightened way. The early chapters set Rawls' naturalist belief in common moral development and agreement (which first emerged 20 years before the publication of Theory) against the pluralist shift in Rawls' philosophy by the late 1970s. To be sure, Rawls' invocation of public reason in Political Liberalism as a response to pluralism is recognized as a real deviation from the academic argument contained in Theory. But more than this philosophical shift, Gališanka's careful account of Rawls' intellectual development makes the reader sensitive to the fact that this moderation in his naturalist beliefs was a considerable departure from long-held philosophical beliefs. While some may feel their integrity or status threated by having to depart from ideas first conceived decades earlier and revised and improved in subsequent years, Rawls accepted his fallibility and integrated criticisms without being 
similarly perturbed. Gališanka therefore adds texture to Rawls as an earnest person capable of deferring to the strength of others' arguments and insights at the possible expense of his own standing. These are individual qualities of Rawls as a human being previously revealed only to his contemporaries that Galisanka helps new readers to appreciate for themselves.

Rawls' private papers at Harvard, Princeton, and Cornell University archives have only recently been released to the public, and so it is only over the past few years that a reconstruction of Rawls' intellectual development that does not rely upon testimony of his friends, students, and peers has become possible. This goes some way to explain why, as Mark Bevir and Andrius Gališanka note in an earlier piece (2012, p. 701), 'the secondary literature on Rawls is vast, but little of it is historical.' Indeed, this uneven distribution between historical and analytical Rawls literature is present in several prominent texts, including those written by former students Thomas Pogge and Samuel Freeman. This is a shame because the biographical portions of their respective books are valuable, engaging, and, as Gališanka demonstrates, worthy of elaboration. Such elaboration of Rawls' intellectual development reintroduces us to Theory not as some monolithic grand theory, but as a tentative and evolving project that can still be of considerable use to political philosophers in the twenty-first century by continuing to evolve in light of new philosophical insights and arguments.

It is notable that Pogge and Freeman are former students of Rawls who maintained an enduring relationship with him. They are therefore well situated to speak authoritatively about Rawls' character and give anecdotes about his thinking on matters unavailable to political theorists who lack this personal connection. As Rawls retired from Harvard in 1991 and died in 2002, there is, thus, a full generation of political theorists who lack knowledge of the person that was Rawls. This lack regrettably attenuates the relationship between Rawls and new generations of his critics who would benefit from more intimate knowledge of Rawls himself. Andrius Gališanka's new intellectual biography has therefore been published at a very welcome time. Indeed, perhaps the most valuable contribution of this book is the intimate introduction of the reader to Rawls himself, as someone acting in good faith to solve stubborn philosophical problems such as how to overcome disagreement in ethics while recognizing others as equal persons worthy of respect.

Rawls famously wanted to publish his Lectures on the History of Moral Philosophy to make them accessible to a wide readership and because he regarded it as unfair that 'if you were not a friend of a friend of someone who studied ethics at Harvard, you would not have them.' (2000, p. xviii). Andrius Gališanka deserves commendation for manifesting this same spirit by offering his readers a thorough reconstruction of Rawls himself, beyond his published work. This democratization of personal knowledge of Rawls ensures that for the first time the more personal aspects of the development of Rawls' thinking over time are available to us all, not

(C) 2020 Springer Nature Limited. 1470-8914 Contemporary Political Theory Vol. 20, S2, S71-S74 S73 
only to Rawls' friends, colleagues, and contemporaries who studied ethics at Harvard.

\section{References}

Bevir, M. and Gališanka, A. (2012) John Rawls in Historical Context. History of Political Thought 33(4): 701-725.

Bok, P. (2017) To the Mountaintop again: The early rawls and post-protestant ethics in postwar America. Modern Intellectual History 14(1): 153-185.

Forrester, K. (2019) In the shadow of justice: Postwar liberalism and the remaking of political philosophy. Princeton, NJ: Princeton University Press.

Rawls, J. (2000) Lectures on the history of moral philosophy. Cambridge, MA: Harvard University Press.

Publisher's Note Springer Nature remains neutral with regard to jurisdictional claims in published maps and institutional affiliations.

Michael A. Richards

Rutgers University, New Brunswick, NJ 08901, USA

m.a.richards@rutgers.edu 